\title{
UKURAN LEBAR PANGGUL MAHASISWI FAKULTAS KEDOKTERAN UNIVERSITAS SAM RATULANGI DENGAN TINGGI BADAN DI BAWAH 150 CM
}

\author{
Nindi A. Simin \\ Sonny J. R. Kalangi \\ Djon Wongkar
Bagian Anatomi-Histologi Fakultas Kedokteran Universitas Sam Ratulangi Manado
Email: sonnykalangi@yahoo.com

\begin{abstract}
The female hip has a wider lower part which plays an important role in pregnancy and labour. The WHO (1999) reported that there were 180-200 million pregnancies per year with 585,000 deaths of pregnant women due to complications, inter alia a narrow hip. Females with heights of less than $150 \mathrm{~cm}$ have to be suspect of having narrow hips. This study aimed to find out whether female students in the Faculty of Medicine, University of Sam Ratulangi Manado with heights of less than $150 \mathrm{~cm}$ were suspected of having narrow hips. This was a descriptive study. Samples were 60 female students with distantia spinosum less than 24-26 $\mathrm{cm}$ and distantia tuberosum less than $10.5 \mathrm{~cm}$. The results showed that there were 25 students with heights of 147.0-148.9 cm. The smallest distantia spinosum was $15.3 \mathrm{~cm}$ while the smallest distantia tuberosum was $8.3 \mathrm{~cm}$. Conclusion: All female students with heights of less than $150 \mathrm{~cm}$ had distantia spinosum less than normal, but most of them still had normal distantia tuberosum.
\end{abstract}

Keywords: female students, height, distantia spinosum, distantia tuberosum.

\begin{abstract}
Abstrak: Bentuk panggul wanita mempunyai bagian bawah yang lebih luas untuk keperluan kehamilan dan persalinan. Dari data WHO 1999 terdapat 180-200 juta kehamilan setiap tahunnya dan 585 ribu kematian wanita hamil berkaitan dengan komplikasi salah satunya ialah panggul sempit. Wanita dengan tinggi badan kurang dari $150 \mathrm{~cm}$ dapat dicurigai adanya kesempitan panggul. Penelitian ini bertujuan untuk mengetahui apakah mahasiswi Fakultas Kedokteran Universitas Sam Ratulangi Manado dengan tinggi badan kurang dari $150 \mathrm{~cm}$ dapat dicurigai adanya kesempitan panggul. Penelitian ini merupakan studi deskriptif. Sampel didapatkan dari 60 subjek yang memenuhi kriteria dengan tinggi badan yang kurang dari 150 $\mathrm{cm}$, ukuran distansia spinarum kurang dari $24-26 \mathrm{~cm}$ dan distansia tuberum kurang dari 10,5 cm. Penelitian ini menunjukkan bahwa tinggi badan terbanyak yaitu 147,0-148,9 cm berjumlah 25 subjek, ukuran distansia spinarum terkecil 15,3 cm dan distansia tuberum terkecil yaitu $8,3 \mathrm{~cm}$. Simpulan: Karakteristik distansia spinarum $100 \%$ wanita dengan tinggi badan kurang dari $150 \mathrm{~cm}$ mempunyai ukuran panggul yang kurang dari normal dan distansia tuberum didapatkan sebagian besar wanita dengan tinggi badan kurang dari $150 \mathrm{~cm}$ mempunyai ukuran distansia tuberum yang normal.
\end{abstract}

Kata kunci: mahasiswi, tinggi badan, distansia spinarum, distansia tuberum.

Kerangka panggul seorang perempuan lebih ditujukan pada pemenuhan fungsi reproduksi. Bentuk panggul perempuan mempunyai bagian bawah yang lebih luas untuk keperluan kehamilan. Panggul dengan ukuran normal jenis apapun kelahiran pervaginam janin dengan berat badan normal tidak akan mengalami kesukaran. Pengaruh gizi, lingkungan atau hal-hal lain dapat mengakibatkan ukuran- 
ukuran panggul menjadi lebih kecil dari pada standar normal sehingga bisa terjadi kesulitan dalam persalinan per vaginam. ${ }^{1,2}$

Kerangka panggul berhubungan dengan faktor ras sosial ekonomi, serta frekuensi dan ukuran jenis-jenis panggul yang berbeda di antara berbagai bangsa. Dengan demikian, standar untuk panggul normal pada seorang perempuan Eropa berlainan dengan standar seorang perempuan Asia Tenggara. ${ }^{3}$

Dari data WHO 1999 terdapat 180-200 juta kehamilan setiap tahunnya dan 585 ribu kematian wanita hamil berkaitan dengan komplikasi salah satunya ialah panggul sempit. ${ }^{3}$ Menurut Liselele et al, pada perempuan dengan tinggi badan kurang dari $150 \mathrm{~cm}$ dapat dicurigai adanya kesempitan panggul. ${ }^{4}$ Tubuh yang pendek dapat menjadi indikator gangguan genetik karena tinggi badan yang pasti seringkali tidak diketahui dan tinggi badan bertambah seiring peningkatan usia perempuan. ${ }^{5}$

\section{ANATOMI TULANG PANGGUL}

Tulang panggul merupakan tulang berbentuk iregular dan berukuran besar yang berhubungan dengan tulang yang sama pada sisi yang berlawanan. Tulang panggul terdiri dari tiga buah tulang yaitu os koksa (yang terdiri dari ilium, iskium, dan pubis), os sacrum, dan os koksigis; kesemuanya bersatu pada cekungan bagian dalam tulang yang dinamakan asetabulum. Pembentukan penuh tulang ini baru tercapai setelah usia 15-25 tahun. Sebelum usia tersebut, ketiga bagian tulang panggul dihubungkan oleh tulang rawan. ${ }^{6}$

Ilium mencakup bagian atas asetabulum dan bagian pipih yang melebar di atas krista iliaka yang merupakan tempat perlekatan bagi otot-otot lateral dari dinding abdomen. Krista iliaka sedikit menonjol pada bagian bawah dan berakhir di depan, pada spina iliaka anterior superior yang mudah teraba pada ujung lateral lipatan pangkal paha. Spina iliaka superior posterior terdapat tepat di bawah cekungan kecil yang mudah terlihat di bagian belakang pinggang. Ilium juga mempunyai spina iliaka inferior (baik anterior maupun posterior) yang merupakan tempat perlekatan otot-otot besar. Pada bagian belakang terdapat permukaan artikular untuk persendian dengan sakrum di bawahnya; terdapat lubang yang disebut lubang skiatika untuk tempat lewat nervus skiatika. ${ }^{6}$

Iskium membentuk bagian posterior bawah tulang panggul. Terdapat tonjolan besar tulang iskium yang merupakan tempat perlekatan otot-otot dan menahan badan dalam posisi duduk. Pubis membentuk bagian anterior tulang panggul dan bertemu dengan tulang pubis sisi berlawanan pada sendi tulang rawan yang disebut simfisis pubis. ${ }^{6}$

Panggul merupakan suatu cincin tulang yang terdiri dari dua tulang panggul, sakrum dan koksigis. Panggul dibagi menjadi panggul besar dan panggul kecil oleh linea terminalis dan promontorium sakrum. Panggul besar merupakan bagian atas yang pada masing-masing sisi dibatasi oleh ilium dan pada sisi belakang oleh basis tulang sakrum. Hal ini mendukung usus untuk mengirimkan sebagian dari berat badan ke dinding anterior abdomen. ${ }^{6}$

Panggul kecil ialah bagian dari rongga panggul yang terletak di bawah dan di pinggir belakang panggul. Dinding tulang panggul kecil lebih lengkap daripada panggul besar. Untuk memudahkannya, panggul kecil dibagi menjadi bagian dalam yang dibatasi oleh lingkar panggul dan bagian luar yang dibatasi oleh lingkar inferior dan sebuah rongga. ${ }^{\top}$

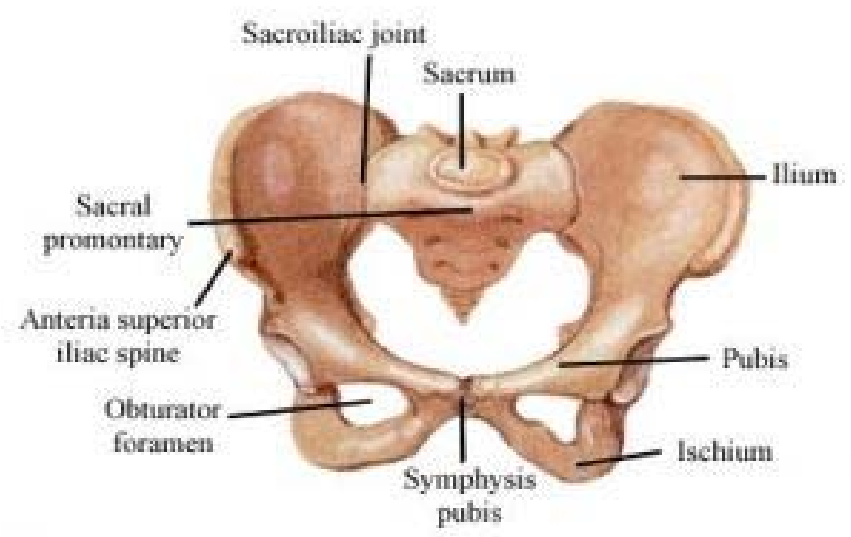

Gambar 1. Anatomi tulang panggul. ${ }^{16}$ 


\section{JENIS PANGGUL}

Menurut anatomi, panggul dibagi menjadi empat jenis utama, antara lain dengan ciri-ciri sebagai berikut: ${ }^{7}$

1. Panggul ginekoid, dengan pintu atas panggul yang bundar atau dengan diameter transversal yang sedikit lebih panjang dari pada diameter anteroposterior, dan dengan panggul tengah serta pintu bawah panggul yang cukup luas. Jenis ini ditemukan pada $45 \%$ perempuan.

2. Panggul antropoid, dengan diameter anteroposterior yang lebih panjang dari pada diameter transversal, dan dengan arkus pubis yang sedikit menyempit. Jenis ini ditemukan pada 35\% perempuan.

3. Panggul android, bentuk pintu atas panggul hampir segitiga. Panjang diameter anteroposterior hampir sama dengan diameter transversal, berhubungan dengan penyempitan kedepan, spina iskiadika menonjol kedalam dan arkus pubis menyempit. Jenis ini ditemukan pada $15 \%$ perempuan.

4. Panggul platipeloid, dengan diameter anteroposterior yang jelas lebih pendek dari pada diameter tranversal pada pintu atas panggul, dan arkus pubis yang luas. Jenis ini ditemukan pada 5\% perempuan.

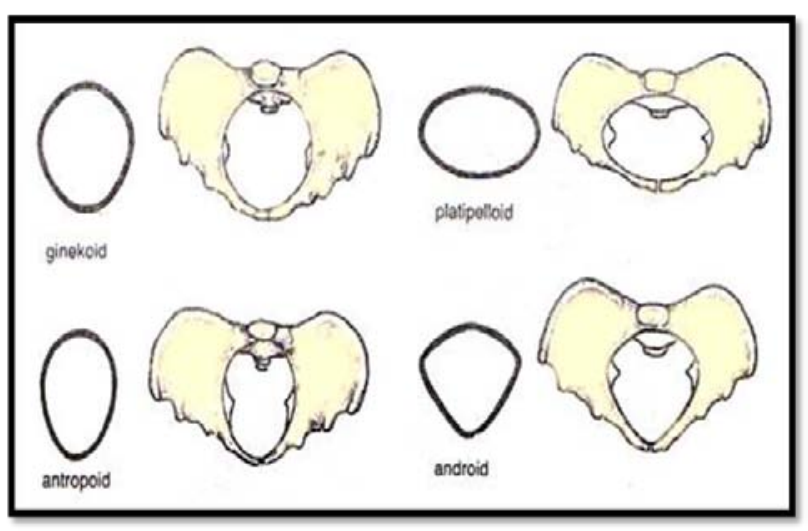

Gambar 2. Jenis-jenis panggul. ${ }^{17}$

\section{DINDING PANGGUL}

Dinding panggul dapat dibedakan atas dinding ventral, dua dinding lateral, dinding dorsal, dan dasar panggul. ${ }^{8}$

a. Dinding panggul ventral dibentuk oleh kedua korpus os pubis, ramus os pubis, serta simfisis pubis.

b. Dinding panggul lateral memiliki kerangka tulang yang dibentuk oleh bagian-bagian os koksa. Muskulus obturator internus menutupi hampir seluruh dinding-dinding ini. Masingmasing muskulus obturator internus meninggalkan panggul melalui foramen iskiadikum minus yang melekat pada femur.

c. Dinding panggul dorsal dibentuk oleh sakrum, bagian-bagian os iskium yang berdekatan. Muskulus piriformis melapisi dinding di sebelah lateral. Masingmasing muskulus piriformis meninggalkan pelvis minor melalui foramen iskiadikum mayor.

d. Dasar panggul dibentuk oleh otot-otot dasar panggul yang mendukung visera menghasilkan fungsi sfingter pada rektum dan vagina, serta membantu meningkatkan tekanan intraabdominal saat bergerak. Rektum, uretra, dan vagina melewati dasar panggul dan menuju ke luar. Muskulus levator ani dan muskulus koksigeus membentuk dasar panggul sedangkan muskulus piriformis menutupi bagian depan sakrum.

\section{UKURAN-UKURAN PANGGUL YANG DAPAT DIUKUR DARI LUAR ${ }^{9}$}

a. Distansia spinarum, yaitu jarak antara kedua spina iliaka anterior superior dekstra dan sinistra. Nilai normalnya \pm 24-26 cm.

b. Distansia tuberum, yaitu jarak antara tuber iskii kanan dan kiri. Nilai normalnya $\pm 10,5 \mathrm{~cm}$.

c. Distansia kristarum yaitu jarak antara kedua krista iliaka dekstra dan sinistra. Nilai normalnya $\pm 28-30 \mathrm{~cm}$.

d. Distansia oblikua eksterna, yaitu jarak antara spina iliaka posterior sinistra dan spina iliaka anterior dekstra dan dari 
spina iliaka posterior dekstra ke spina iliaka anterior sinstra.

e. Distansia intertrokanterika, yaitu jarak antara kedua trokanter mayor.

f. Konjugata eksterna, yaitu jarak antara bagian atas simfisis ke prosesus spinosus lumbal V. Nilai normalnya $\pm 18 \mathrm{~cm}$.

\section{STRUKTUR TINGGI BADAN MANU- SIA}

Struktur tubuh manusia terdiri atas berbagai macam organ yang tersusun sedemikian rupa satu dengan yang lainnya, sehingga membentuk tubuh manusia seutuhnya; dan kerangka ialah struktur keras pembentuk tinggi badan. ${ }^{10}$

Proses pertumbuhan dimulai sejak terjadi konsepsi dan berlangsung terus menerus sampai dewasa, kemudian menjadi stabil, dan pada usia relatif tua akan kembali berkurang. Pada saat sesudah dilahirkan, usia dapat diperkirakan sesuai golongan pertumbuhan dan perkembangan badan antara bayi, anak-anak, dan dewasa muda. ${ }^{11}$

Pertumbuhan tinggi badan hampir seluruhnya terjadi akibat pertumbuhan tulang rangka yang dianggap sebagai pengukuran pertumbuhan umum yang stabil. Pertumbuhan tinggi badan tidak terjadi terus-menerus di sepanjang kehidupan tetapi berhenti jika maturasi tulang rangka sudah selesai. Panjang yang maksimal terjadi sebelum kelahiran, tetapi bayi baru lahir terus bertumbuh dengan kecepatan yang cepat meskipun lebih lambat. ${ }^{12}$

Dalam memperkirakan tinggi badan seseorang, maka harus diperhatikan bahwa pembentukan tinggi badan seseorang memang sudah dimulai sejak masih dalam kandungan (intra-uterin), dan pertumbuhan tinggi badan tersebut akan terus bertambah ukurannya hingga usia sekitar 20-21 tahun. Setelah usia tersebut pertumbuhan tinggi badan tidak lagi nyata dan akan berkurang seiring dengan pertambahan usia. ${ }^{13}$

\section{PERTUMBUHAN TULANG}

Kerangka merupakan organ penyangga tubuh manusia sehingga tubuh dapat berdiri tegak. Terdapat sekitar 206 jumlah tulang manusia dewasa yang membentuk tubuh manusia, sedangkan pada anak-anak jumlah tersebut sebenarnya lebih dari 300 tulang. Proses pertumbuhan anak-anak menjadi dewasa menyebabkan terjadinya penyatuan beberapa tulang sehingga ketika dewasa jumlahnya menjadi sedikit. ${ }^{14}$

Pembentukan tulang dimulai selama bulan kedua kehidupan janin ketika garam kalsium disimpan di dalam substansi intrasel atau matriks untuk membentuk kartilago yang terkalsifikasi terlebih dahulu, dan kemudian terjadi kalsifikasi tulang yang sebenarnya.

Terdapat beberapa perbedaan dalam pembentukan tulang. Pada tulang pendek, osifikasi terbentuk dibagian tengah dan kartilago terus menyebar dipermukaan. Pada tulang panjang, osifikasi dimulai di diafisis atau bagian tengah tulang dan berlanjut ke epifisis atau bagian ujung tulang. Antara diafisis dan epifisis, plat kartilago epifisis disatukan dengan diafisis oleh jaringan spongiosa metafisis. ${ }^{13}$

\section{FAKTOR YANG MEMENGARUHI PERTUMBUHAN DAN PERKEM- BANGAN}

Faktor-faktor yang memengaruhi pertumbuhan dan perkembangan dibedakan menjadi faktor internal dan faktor eksternal. Faktor internal meliputi faktor genetik dan faktor hormonal sehingga tidak semua orang memiliki tinggi badan yang sama. Kemampuan menjadi tinggi diwariskan oleh kedua orang tuanya, sehingga anak yang tinggi biasanya berasal dari orang tua yang tinggi pula. Faktor hormonal yang memengaruhi pertumbuhan yaitu hormon pertumbuhan hipofisis yang memengaruhi pertumbuhan sel-sel tulang; hormon tiroid yang memengaruhi pertumbuhan dan pematangan tulang; serta hormon kelamin dan kelenjar suprarenalis yang bekerja terutama pada masa pubertas. ${ }^{15}$

Faktor eksternal meliputi lingkungan prenatal yaitu kurangnya asupan makanan 
selama kehamilan, infeksi virus dan penyakit lainnya yang dapat menyebabkan kemunduran mental, catat tubuh dan kelainan jantung. Lingkungan pasca kelahiran meliputi kurangnya asupan bahan makanan pembangun tubuh terutama protein yang dapat menganggu pertumbuhan. Keadaan sosial ekonomi memegang peran penting dalam pertumbuhan. Faktor lain yang juga mempengaruhi pertumbuhan yaitu perbaikan sanitasi, pendidikan, dan faktor psikologi. ${ }^{15}$

\section{METODE PENELITIAN}

Penelitian ini bersifat deskriptif dengan mengukur lebar panggul pada mahasiswi Fakultas Kedokteran Universitas Sam Ratulangi Manado dengan tinggi badan di bawah $150 \mathrm{~cm}$.

Penelitian ini dilakukan di Fakultas Kedokteran Universitas Sam Ratulangi pada bulan November sampai Desember 2011. Yang menjadi subyek penelitian ialah semua mahasiswi yang mempunyai tinggi badan di bawah $150 \mathrm{~cm}$. Variabel penelitian ialah tinggi badan dan lebar panggul. Analisis data dilakukan dengan SPSS (Statistical Package for the Social Science) 15.0 for Windows Evaluation Version.

\section{Definisi operasional}

1. Tinggi badan ialah jarak dari tumit sampai verteks dalam posisi tegak lurus.

2. Lebar panggul yang diukur:

a. Distansia spinarum diukur dari jarak antara spina iliaka anterior superior kanan dan kiri.

b. Distansia tuberum diukur dari jarak antara tuber iskii kanan dan kiri.

\section{HASIL PENELITIAN}

\section{Karakteristik subjek penelitian}

Subjek penelitian ialah mahasiswi Fakultas Kedokteran Universitas Sam Ratulangi dengan kisaran tinggi badan di bawah $150 \mathrm{~cm}$. Subjek yang memenuhi kriteria sebanyak 60 orang mahasiswi.

Distribusi tinggi badan yang paling banyak terdapat pada kelompok tinggi badan 147,0-148,9 cm berjumlah 25 subjek (41,67\%), sedangkan yang paling sedikit pada kelompok tinggi badan 143,0-144,9 cm berjumlah tiga subjek (5\%) (Tabel 1).

Distribusi distansia spinarum paling banyak pada kelompok lebar panggul 21,021,9 cm berjumlah 22 subjek (36,67\%), sedangkan jumlah yang paling sedikit pada kelompok lebar panggul 23,0-23,9 cm berjumlah satu subjek (1,67\%) (Tabel 2).

Tabel 3 memperlihatkan bahwa seluruh subjek (100\%) mempunyai ukuran distansia spinarum yang kurang dari normal.

Berdasarkan Tabel 4, lebar distansia tuberum paling banyak pada kelompok lebar panggul 10,0-10,9 cm dan 12,0-12,9 $\mathrm{cm}$ berjumlah 17 subjek (28,33\%), sedangkan yang paling sedikit pada kelompok lebar panggul 8,0-8,9 cm berjumlah dua subjek (3,33\%).

Berdasarkan Tabel 5, sebagian besar sampel (81,7\%) mempunyai ukuran distansia tuberum yang normal.

Tabel 1. Distribusi tinggi badan.

\begin{tabular}{ccccccc}
\hline $\begin{array}{c}\text { Tinggi badan } \\
(\mathbf{c m})\end{array}$ & Jumlah & $\mathbf{\%}$ & $\begin{array}{c}\text { Min } \\
(\mathbf{c m})\end{array}$ & $\begin{array}{c}\text { Max } \\
(\mathbf{c m})\end{array}$ & $\begin{array}{c}\text { Mean } \\
(\mathbf{c m})\end{array}$ & $\begin{array}{c}\text { Std. } \\
\text { Deviasi } \\
(\mathbf{c m})\end{array}$ \\
\hline $143,0-144,9$ & 3 & 5 & 143,5 & 144,0 & 143,73 & 0,2517 \\
$145,0-146,9$ & 11 & 18,33 & 145,0 & 146,9 & 145,77 & 0,6342 \\
$147,0-148,9$ & 25 & 41,67 & 147,0 & 148,9 & 148,20 & 0,4954 \\
$149,0-150,9$ & 21 & 35 & 149,0 & 149,8 & 149,36 & 0,2519 \\
\hline Total & $\mathbf{6 0}$ & $\mathbf{1 0 0}$ & $\mathbf{1 4 4}$ & $\mathbf{1 4 9}$ & $\mathbf{1 4 7 , 6 5}$ & $\mathbf{1 , 4 9 4}$ \\
\hline
\end{tabular}


Tabel 2. Distribusi distansia spinarum.

\begin{tabular}{ccccccc}
\hline $\begin{array}{c}\text { Distansia } \\
\text { Spinarum (cm) }\end{array}$ & Jumlah & $\mathbf{\%}$ & $\begin{array}{c}\text { Min } \\
\mathbf{( c m )}\end{array}$ & $\begin{array}{c}\text { Max } \\
\mathbf{( c m )}\end{array}$ & $\begin{array}{c}\text { Mean } \\
\mathbf{( c m )}\end{array}$ & $\begin{array}{c}\text { Std. } \\
\text { Deviasi } \\
(\mathbf{c m})\end{array}$ \\
\hline $15,0-15,9$ & 2 & 3,33 & 15,3 & 15,5 & 15,40 & 0,1414 \\
$16,0-16,9$ & 3 & 5,00 & 16,0 & 16,5 & 16,17 & 0,2887 \\
$17,0-17,9$ & 0 & 0 & 0 & 0 & 0 & 0 \\
$18,0-18,9$ & 5 & 8,33 & 18,0 & 18,4 & 18,26 & 0,1517 \\
$19,0-19,9$ & 7 & 11,67 & 19,0 & 19,8 & 19,37 & 0,2928 \\
$20,0-20,9$ & 14 & 23,33 & 20,0 & 20,8 & 20,42 & 0,2694 \\
$21,0-21,9$ & 22 & 36,67 & 21,0 & 21,8 & 21,23 & 0,2607 \\
$22,0-22,9$ & 6 & 10,00 & 22,0 & 22,7 & 22,20 & 0,3162 \\
$23,0-23,9$ & 1 & 1,67 & 23,3 & 23,3 & 23,30 & 0 \\
\hline Total & $\mathbf{6 0}$ & $\mathbf{1 0 0}$ & $\mathbf{1 5 , 3}$ & $\mathbf{2 3 , 3}$ & $\mathbf{2 0 , 2 6 2}$ & $\mathbf{1 , 7 4 5 0}$ \\
\hline
\end{tabular}

Tabel 3. Karakteristik distansia spinarum berdasarkan antropometri.

\begin{tabular}{ccc}
\hline $\begin{array}{c}\text { Ukuran distansia } \\
\text { spinarum }\end{array}$ & Jumlah & $\%$ \\
\hline $\begin{array}{c}\text { Normal } \\
<\text { Normal }\end{array}$ & 0 & 0 \\
Total & 60 & 100 \\
\hline
\end{tabular}

Tabel 4. Distribusi distansia tuberum.

\begin{tabular}{ccccccc}
\hline $\begin{array}{c}\text { Distansia } \\
\text { tuberum } \\
(\mathbf{c m})\end{array}$ & Jumlah & $\mathbf{\%}$ & $\begin{array}{c}\text { Min } \\
\mathbf{( c m})\end{array}$ & $\begin{array}{c}\text { Max } \\
\mathbf{( c m )}\end{array}$ & $\begin{array}{c}\text { Mean } \\
\mathbf{( c m )}\end{array}$ & $\begin{array}{c}\text { Std. } \\
\text { Deviasi } \\
(\mathbf{c m})\end{array}$ \\
\hline $8,0-8,9$ & 2 & 3,3 & 8,3 & 8,4 & 8,35 & 0,0707 \\
$9,0-9,9$ & 9 & 15 & 9,0 & 9,8 & 9,49 & 0,2619 \\
$10,0-10,9$ & 17 & 28,4 & 10,0 & 10,7 & 10,25 & 0,2741 \\
$11,0-11,9$ & 11 & 18,3 & 11,0 & 11,7 & 11,36 & 0,2461 \\
$12,0-12,9$ & 17 & 28,3 & 12,0 & 12,8 & 12,23 & 0,2953 \\
$13,0-13,9$ & 4 & 6,7 & 13,0 & 13,0 & 13,00 & 0,0000 \\
\hline Total & $\mathbf{6 0}$ & $\mathbf{1 0 0}$ & $\mathbf{8 , 3}$ & $\mathbf{1 3 , 0}$ & $\mathbf{1 1 , 0 2 0}$ & $\mathbf{1 , 2 4 2}$ \\
\hline
\end{tabular}

Tabel 5. Karakteristik distansia tuberum berdasarkan antropometri.

\begin{tabular}{ccc}
\hline $\begin{array}{c}\text { Ukuran distansia } \\
\text { tuberum } \\
(\mathbf{c m})\end{array}$ & Jumlah & $\mathbf{\%}$ \\
\hline Normal & 49 & 81,7 \\
$<$ Normal & 11 & 18,3 \\
\hline Total & $\mathbf{6 0}$ & $\mathbf{1 0 0}$ \\
\hline
\end{tabular}




\section{BAHASAN}

Tubuh yang pendek dapat menjadi indikator gangguan genetik karena tinggi badan yang pasti seringkali tidak diketahui dan tinggi badan bertambah seiring peningkatan usia wanita. $^{5}$ Menurut Liselele, pada wanita dengan tinggi badan kurang dari $150 \mathrm{~cm}$ dapat dicurigai adanya kesempitan panggul; ${ }^{4}$ oleh karena itu penelitian ini dilakukan pada wanita dengan tinggi badan kurang dari $150 \mathrm{~cm}$. Pada penelitian ini didapatkan tinggi badan terbanyak yaitu 147,0-148,9 cm, yaitu 25 subjek (41,67\%).

Ukuran normal distansia spinarum ialah $\pm 24-26 \mathrm{~cm}$. Distansia spinarum dikatakan kurang dari normal jika ukurannya kurang dari $24 \mathrm{~cm}^{9}{ }^{9}$ Dalam penelitian ini didapatkan ukuran distansia spinarum terkecil $15,3 \mathrm{~cm}$. Yang paling banyak dijumpai (36,67\%) ialah subjek dengan ukuran distansia spinarum di kisaran 21,0-21,9 cm. Berdasarkan karakteristik distansia spinarum didapatkan 100\% wanita dengan tinggi badan kurang dari $150 \mathrm{~cm}$ mempunyai ukuran panggul yang kurang dari normal. Hasil penelitian ini serupa dengan yang dilakukan oleh Aflah N di RSUP H. Adam Malik yang mendapatkan sebagian besar $(80,0 \%)$ wanita dengan tinggi badan kurang dari $150 \mathrm{~cm}$ mempunyai distansia spinarum yang kurang dari normal. ${ }^{18}$

Distansia tuberum yaitu jarak antara tuber iskii kanan dan kiri, dan dikatakan normal jika ukurannya $\pm 10,5 \mathrm{~cm} .^{9}$ Dalam penelitian ini didapatkan distansia tuberum terendah ialah 8,3 cm. Yang paling banyak dijumpai (28,3\%) yaitu subjek dengan ukuran distansia tuberum di kisaran 12,012,9 cm. Berdasarkan karakteristik distansia tuberum didapatkan sebagian besar wanita dengan tinggi badan kurang dari $150 \mathrm{~cm}$ mempunyai ukuran distansia tuberum yang normal. Berbeda dengan penelitian yang dilakukan Aflah $\mathrm{N}$ yang mendapatkan sebagian besar (70,8\%) mempunyai ukuran distansia tuberum yang kurang dari normal. ${ }^{18}$

\section{SIMPULAN}

Berdasarkan hasil penelitian pada mahasiswi Fakultas Kedokteran Unsrat dengan tinggi badan kurang dari $150 \mathrm{~cm}$ dapat disimpulkan bahwa sebagian besar subjek mempunyai tinggi badan di kisaran 147,0-148,9 cm, ukuran distansia spinarum terbanyak 21,0-21,9 cm, dan ukuran distansia tuberum terbanyak 10,0-10,9 cm dan 12,0-12,9 cm.

\section{DAFTAR PUSTAKA}

1. Wiknjosastro H. Anatomi panggul dan isinya. In: Saifudin AB, Trijatmo R, editors. Ilmu Kandungan (Edisi ke-4). Jakarta: PT. Bina Pustaka Sarwono Prawirohardjo, 2009; h.1.

2. Wiknjosastro H. Distosia karena kelainan panggul. Saifudin AB, Trijatmo R, editors. Ilmu Kebidanan (Edisi ke-3). Jakarta: PT. Bina Pustaka Sarwono Prawirohardjo, 2006; h.637-47.

3. Mochtar R. Panggul sempit (Pelvic contraction). Lutan D, editor. Synopsis Obstetri (Edisi ke-2). Jakarta: Penerbit Buku Kedokteran EGC, 1998; h.332.

4. Liselele HB, Boulvan M, Tshibangu KC, Meuris S. Maternal height and external pelvimetry to predict cephalopelvic disproportion in nulliparous African women: A Cohort study. BJOG Maret 2001.

5. Wheeler L. Perawatan Pranatal dan Pascapartum (Edisi ke-1). Jakarta: Penerbit Buku Kedokteran EGC, 2003; h.71.

6. Wibowo SD. Anatomi Tubuh Manusia (Edisi ke-1). Jakarta: Grasindo, 2004; h.9-10.

7. Rachimbadhi T. Anatomi jalan lahir. Saifudin $A B$, editor. Ilmu Kebidanan (Edisi ke-4). Jakarta: PT. Bina Pustaka Sarwono Prawirohardjo, 2009; h.188.

8. Gray H. Anatomy of the Human Body [electronic resource]. New York: Bartleby.com, 2000; p.5.

9. Yulaikhah L. Kehamilam. Seri Asuhan Kebidanan. Jakarta: Penerbit Buku Kedokteran EGC, 2008; h.16-17.

10. McMinn RMH, Hutchings RT, Pegington J, et al. A Colour Atlas of Human Anatomy (Third Edition). London: Wolfe Publishing: 1993. p. 99-154.

11. Amir A. Identifikasi. In: Rangkaian Ilmu 
S100 Jurnal Biomedik, Volume 4, Nomor 3, Suplemen, November 2012, hlm. 93-100

Kedokteran Forensik (Edisi ke-2). Medan: Bagian Ilmu Kedokteran Forensik FK-USU, 2005; h.178-203.

12. Wong LD, Eaton HM, Wilson D, Winkelstein LM, Schwartz P. Buku Ajar Keperawatan Pediatrik (Edisi ke6). Jakarta: Penerbit Buku Kedokteran EGC, 2002; p.112.

13. Byers SN. Basic of human osteology and odontology. In: Introduction to Forensic Anthropologi (Third Edition). Boston: Allyn and Bacon, 2008; p.28-59.

14. Snell RS. Anatomi Klinik untuk Mahasiswa Kedokteran Bagian 1 (Edisi ke-3). Alih Bahasa Dharma A. Jakarta: Penerbit Buku Kedokteran EGC, 1997; h.34-6.

15. Deswaty F. Faktor-faktor yang mempengaruhi pertumbuhan dan perkembangan manusia. Seri IPA Biologi (Edisi ke-2). Bandung: Penerbit Yudhistira, 2007; h.36-7.

16. Panggul wanita [image on the Internet]. Nodate [updated 2011 Jan; cited 2011 Nov 22]. Available from: http://sehataja-yuk.blogspot.com/2011/08/panggulwanita.html.

17. Jenis-jenis panggul [image on the Internet]. Nodate [updated 2011 Jan; cited 2012 Feb 2]. Available from: http://sehat-ajayuk.blogspot.com/2011/08/panggulwanita.html.

18. Aflah N. Ukuran panggul pada pasien pasca seksio sesaria atas indikasi panggul sempit [Tesis]. Medan: RSUP H. Adam Malik/RSUD Dr. Pirngadi Universitas Sumatra Utara Medan; 2009; h.17. 